\title{
Tick-borne pathogens of zoonotic and veterinary importance in Nigerian cattle
}

\author{
Vincenzo Lorusso ${ }^{1}$, Michiel Wijnveld ${ }^{2}$, Ayodele O. Majekodunmi ${ }^{1}$, Charles Dongkum ${ }^{3}$, Akinyemi Fajinmi ${ }^{3}$, \\ Abraham G. Dogo ${ }^{4}$, Michael Thrusfield ${ }^{5}$, Albert Mugenyi ${ }^{1}$, Elise Vaumourin ${ }^{6}$, Augustine C. Igweh ${ }^{3}$, \\ Frans Jongejan ${ }^{2,7}$, Susan C. Welburn ${ }^{1}$ and Kim Picozzi ${ }^{1 *}$
}

\begin{abstract}
Background: Ticks and tick-borne diseases undermine cattle fitness and productivity in the whole of sub-Saharan Africa, including Nigeria. In this West African country, cattle are challenged by numerous tick species, especially during the wet season. Consequently, several TBDs are known to be endemic in Nigerian cattle, including anaplasmosis, babesiosis, cowdriosis and theilerioris (by Theileria mutans and Theileria velifera). To date, all investigations on cattle TBDs in Nigeria have been based on cytological examinations and/or on serological methods. This study aimed to ascertain the occurrence of tick-borne pathogens of veterinary and zoonotic importance in cattle in Nigeria using molecular approaches.
\end{abstract}

Methods: In October 2008, 704 whole blood samples were collected from indigenous cattle in the Plateau State, Nigeria. Analysis for tick-borne pathogens was conducted by means of PCR-based reverse line blotting (RLB) and sequencing targeting a panel of five genera of microorganisms (i.e. Babesia, Theileria, Anaplasma, Ehrlichia and Rickettsia spp.).

Results: In total, 561/704 (82.6\%) animals were found infected, with 465 (69.6\%) of them being infected by two or more microorganisms, with up to 77 possible combinations of pathogens detected. Theileria mutans was the most prevalent microorganism (66.3\%), followed by Theileria velifera (52.4\%), Theileria taurotragi (39.5\%), Anaplasma marginale (39.1 \%), Anaplasma sp. (Omatjenne) (34.7\%), Babesia bigemina (7.9 \%), Anaplasma centrale (6.3\%), Anaplasma platys (3.9\%), Rickettsia massiliae (3.5\%), Babesia bovis (2.0 \%) and Ehrlichia ruminantium (1.1\%). Calves were found significantly less infected than juvenile and adult cattle.

Conclusions: This study provides updated, molecular-based information on cattle TBDs in Nigeria. The molecular approach employed allowed the diagnosis of numerous positive cases including carrier statuses, multiple infections and novel pathogen detections within the indigenous cattle population. Moreover, the RLB method here described enabled the detection of veterinary agents not only pertaining to bovine health, including also those of zoonotic importance.

The high prevalence recorded for T. mutans, T. velifera, A. marginale, T. taurotragi and Anaplasma sp. (Omatjenne), suggests they may be endemically established in Nigeria, whereas the lower prevalence recorded for other microorganisms (i.e. A. centrale and B. bovis) highlights a less stable epidemiological scenario, requiring further investigations.

Keywords: Cattle, Nigeria, Africa, Tick-borne diseases, Tick-borne pathogens, Zoonoses, Fulani

\footnotetext{
* Correspondence: kim.picozzi@ed.ac.uk

${ }^{1}$ Division of Infection and Pathway Medicine, School of Biomedical Sciences,

The University of Edinburgh, Edinburgh, UK

Full list of author information is available at the end of the article
} 


\section{Background}

Ticks and tick-borne diseases (TBDs) threaten livestock health, welfare and productivity in the whole of subSaharan Africa (SSA) [1]. Nigeria is the most populous African country [2], where the cattle population is of approximately 20 million heads, eighty-per-cent of which are concentrated in the North-Central regions [3]. Here, the majority of cattle, being mostly of indigenous species (i.e. Bos indicus), are kept according to the traditional pastoral management of the Fulani herdsmen [4]. Reared under year-round extensive grazing, cattle are challenged by numerous tick species, especially during the wet season (i.e. June to October) when the tick burdens reach the highest abundance [5]. These ticks [i.e. Rhipicephalus decoloratus; Rhipicephalus annulatus; Rhipicephalus guilhoni; Rhipicephalus geigyi; Hyalomma truncatum; Amblyomma variegatum; Rhipicephalus simus Group; Rhipicephalus turanicus; Rhipicephalus sanguineus (sensu lato); Hyalomma rufipes and Rhipicephalus lunulatus] [6] include the vectors of pathogens of veterinary and zoonotic importance (i.e. Anaplasma spp., Ehrlichia spp., Rickettsia spp., Babesia spp. and Theileria spp.) [1].

Regardless of the tick burden on their livestock, the Fulani pastoralists do not usually employ acaricides, merely relying on the manual removal of the most conspicuous tick specimens from certain body sites (e.g. udder) of their cattle in order to minimise losses of milk yields due to infestation [5]. This approach, however, does not keep the animals entirely tick-free, neither does it prevent them from being re-infested nor infected by tick-transmitted pathogens [6]. Moreover, by manually removing certain tick species (i.e. A. variegatum), the Fulani herders are inevitably exposed to tick bites and, consequently, to the zoonotic pathogens they may transmit [e.g. spotted fever group (SFG) rickettsiae] [7-9].

Several TBDs are known to be endemic in Nigerian cattle, including anaplasmosis (by Anaplasma marginale mainly), babesiosis (by Babesia bigemina and Babesia bovis), cowdriosis (by Ehrlichia ruminantium) and theilerioris (by Theileria mutans and Theileria velifera) [1012]. With regards to bovine anaplasmosis, the literature currently lacks confirmation of the presence of $A$. centrale in northern Nigeria [10]. In the indigenous cattle population, these TBDs are usually associated with subclinical or chronic conditions which are difficult to diagnose promptly in the field. However, several concomitant factors such as malnutrition, pregnancy and lactation, further concurrent infection (e.g. trypanosomiasis, haemonchosis, etc.) and/or the particularly high tick burdens of the wet season, can favour the onset of clinically apparent acute TBDs [4, 13]. Importantly, cattle can be infected by several of these pathogens simultaneously, complicating the clinical presentation and the diagnosis of TBDs [14]. Moreover, TBDs display with high morbidity and mortality in exotic cattle (i.e. Bos taurus) when introduced in the area for crossbreeding purposes, thus representing a major limitation to the improvement of cattle production in the country [15].

To date, all investigations of tick-borne pathogens in cattle from Nigeria have been based on cytological examinations of blood smears and lymph node biopsies $[10,11,14-16]$ and/or on serological methods [15-19].

The present study aimed to investigate, by molecular means, the occurrence of tick-borne microorganisms, of both veterinary and zoonotic importance, infecting cattle in an area of North-Central Nigeria where no acaricidebased vector control is usually undertaken, and a high tick challenge and species diversity was previously documented [6]. This study relied on the application of a broad spectrum reverse line blotting (RLB) combining three different polymerase chain reaction (PCR) approaches [20-27], enabling the detection of microorganisms belonging to the genera Babesia, Theileria, Anaplasma, Ehrlichia, and Rickettsia.

The finding will contribute to a better understanding of the epidemiology of cattle TBDs in Nigeria, also assessing the risks for potential transmission of zoonotic pathogens to humans. Results generated would ultimately help orientate field diagnosis of bovine TBDs as well as the designing of control strategies in Nigeria, and may serve as a model for other West African countries.

\section{Methods \\ Study area}

The study was conducted in nine villages belonging to three neighbouring local government areas (LGAs), namely Bokkos, Mangu and Pankshin, in the central part of Plateau State, Nigeria $\left(9.14^{\prime}-9.59^{\prime} \mathrm{N}, 8.84^{\prime}-9.38^{\prime} \mathrm{E}\right)$, as part of a larger study focusing on trypanosomiasis [28] (Fig. 1).

The study area falls within the Northern Savannah vegetation zone, in the sub-humid region of Nigeria, where the dry season generally extends from November to April, and the wet season from April-May to October, with most (approximately $80 \%$ ) of the rains occurring between June and September [29].

All cattle reared in the area are of indigenous species (i.e. B. indicus), of which approximately $80 \%$ belong to the White Fulani breed, and a smaller number are of either Bunaji or White Fulani x Rahaji crossbreeds. Cattle are grazed on communal pastures year-round according to the traditional Fulani herding system. Other livestock reared in the area include goats, sheep, pigs and poultry. In all villages, dogs are kept as household guards.

\section{Ethics statement}

This study was carried out with the approval of each village chief, the cattle keepers, the Plateau State Ministry 


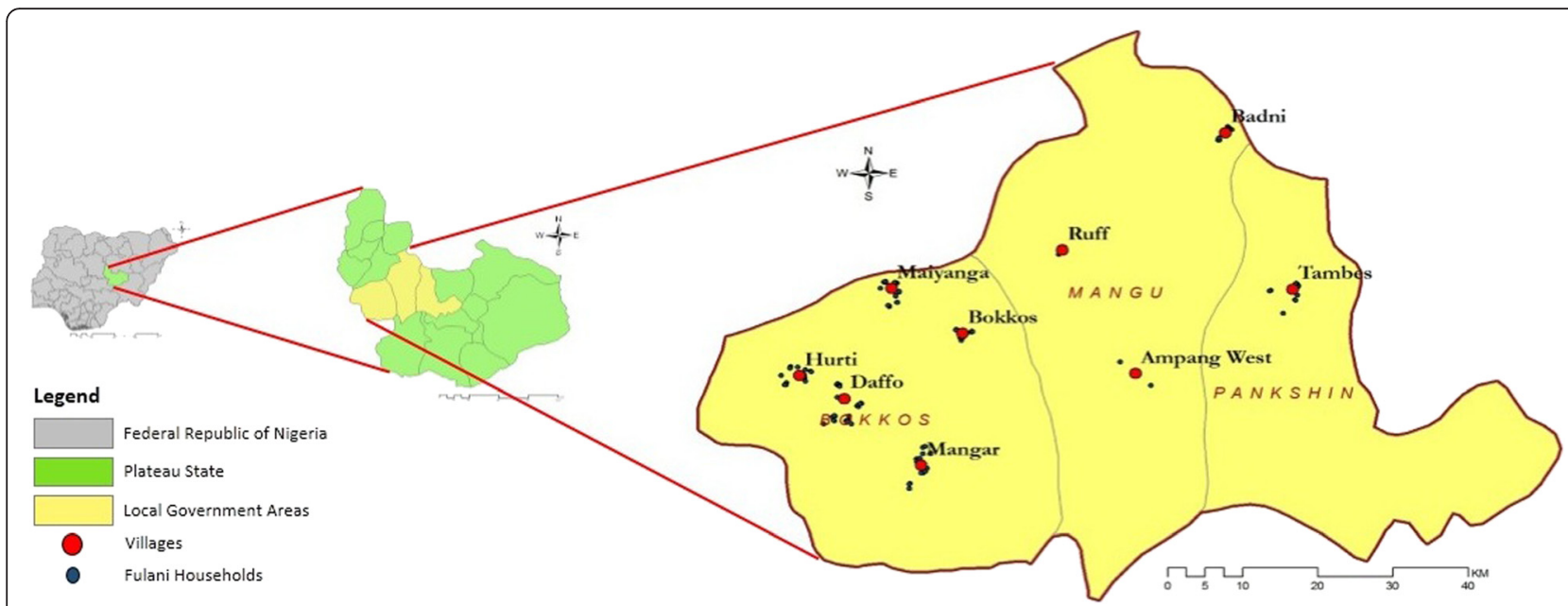

Fig. 1 Map of the study area. Study area including the nine villages where the sampling took place. All three maps (i.e. Nigeria, Plateau State and Local Government Areas of Bokkos, Mangu and Pankshin) were designed using ArcGIS software, version 9.2

of Agriculture and the Ethical Committee on Animal Use and Care at the Nigerian Institute for Trypanosomiasis Research (NITR), Vom, Nigeria. All cattle enrolled in the study were selected and sampled with the agreement of their owners and the chiefs of the villages.

All sampled animals were restrained with the help of their owners and handled humanely.

\section{Sample collection}

Seven-hundred-and-four indigenous ( $B$. indicus) cattle of various sex and age (i.e. 43 calves, 184 juveniles and 477 adults) were randomly selected in nine villages, identified as a subset of a previously conducted cluster sampling [28] for being representative of the agro-ecological zone, the cattle population and management in the Plateau State, North-Central Nigeria.

Age of the animals was estimated on the basis of the dentition score method developed for zebu cattle under a low plane of nutrition [30] and on the information provided by their owners. Once quantified, each animal's age was recorded either as 'calf' (0-6 months), 'juvenile' (6-24 months), or 'adult' (older than 24 months).

Whole blood samples were collected from each of the selected animals by jugular venipuncture and approximately $100 \mu \mathrm{l}$ were applied onto Whatman FTA $^{\mathrm{Tm}}$ cards (Whatman Biosciences, Cambridge, UK). After being allowed to air-dry over night at room temperature, all samples were placed in foil pouches with a silica desiccant and mailed to the University of Edinburgh to be subjected to molecular processing.

\section{DNA extraction and elution}

Once in the laboratory, a protocol for DNA extraction and dilution was followed [31]. Briefly, five three mmcircular portions of each sample-saturated matrix of each FTA $^{\mathrm{TM}}$ card were punched using a Harris Micro Punch $^{\mathrm{TM}}$ (Whatman BioSciences, Cambridge, UK) and placed in a sterile $1.5 \mathrm{ml}$ eppendorf tube. Discs were then washed twice for $15 \mathrm{~min}$ in $1 \mathrm{ml}$ of FTA ${ }^{\mathrm{mm}}$ purification reagent (Whatman BioSciences, Cambridge, UK) to remove any PCR inhibitors from the sample, and rinsed twice for $15 \mathrm{~min}$ in $1 \mathrm{ml}$ of $1 \mathrm{x}$ Tris-EDTA buffer (Sigma-Aldrich Ltd, Dorset, UK) to remove traces of FTA $^{\mathrm{TM}}$ purification reagent. Each test sample (i.e. 5 discs) was then carefully transferred to a sterile $0.2 \mathrm{ml}$ PCR tube and allowed to air-dry at $37^{\circ} \mathrm{C}$ for $40 \mathrm{~min}$.

Afterwards, each samples' DNA was eluted by adding $100 \mu \mathrm{l}$ of $5 \%$ Chelex $^{\oplus} 100$ (Sigma-Aldrich Ltd, Dorset, UK) solution to each PCR tube and incubating at $90{ }^{\circ} \mathrm{C}$ for $30 \mathrm{~min}$ in a Dyad Peltier thermal cycler ${ }^{\odot}$ (MJ Research Inc., USA).

\section{PCR}

After elution, each sample was subjected to three PCR amplifications targeting a 460-540 bp long fragment from the V4 hypervariable region of the $18 \mathrm{~S}$ ribosomal RNA (rRNA) gene for Theileria and Babesia spp. [20], a 460-520 bp long fragment from the V1 hypervariable region of the 16S SSU rRNA gene for Ehrlichia and Anaplasma spp. [21, 22], and a 350-400 bp variable region in the 16S rRNA gene for Rickettsia spp. [23] (see also Table 1).

Each PCR was carried out on a total volume of $25 \mu \mathrm{l}$, using $5 \mu \mathrm{l}$ of $5 \times$ Phire reaction buffer (Thermo Scientific, USA), $0.5 \mu$ of $10 \mathrm{mM}$ dNTPs (Rovalab GmbH, Germany), $0.5 \mu \mathrm{l}$ of $20 \mathrm{pmol} / \mu \mathrm{l}$ of each forward and reverse primer (Integrated DNA Technologies, Inc., USA), 0.25 units of Phire Hot Start II DNA polymerase (Thermo Scientific, USA), $15.875 \mu$ l of water, and $2.5 \mu \mathrm{l}$ of template DNA. Positive controls included $2.5 \mu \mathrm{l}$ of 
Table 1 Primer sets employed for PCR amplification

\begin{tabular}{llll}
\hline PCR target & Primer & Sequence $\left(5^{\prime}-3^{\prime}\right)$ & Reference \\
\hline Theileria/Babesia spp. 18S rDNA & Forward (RLB-F2) & GACACAGGGAGGTAGTGACAAG & [20] \\
& Reverse (RLB-R2) & Biotin-CTAAGAATTCACCTCTGACAGT & GGAATTCAGAGTTGGATC(A/C)TGG(C/T)TCAG \\
Ehrlichia/Anaplasma spp. 16S rDNA & Forward (16S8FE) & Biotin-CGGGATCCCGAGTTGCCGGGACTT(C/T)TTCT & [22] \\
Rickettsia spp. 16S rDNA & Reverse (BGA1B-new) & GAACGCTATCGGTATGCTTAACACA & [23]
\end{tabular}

DNA from Theileria parva (Acession No.: KJ095110), Ehrlichia canis (Accession No.: KJ095115), and rickettsial DNA > 98 \% similar to Rickettsia africae (Accession No.: JX101606) [32], for the three aforementioned PCRs respectively. The 5' of each reverse primer was labeled with a biotine ligand. Negative controls consisted of $2.5 \mu \mathrm{l}$ of water and $5 \%$ Chelex $^{\oplus} 100$ (Sigma-Aldrich Ltd, Dorset, UK)-eluted blank white paper. To minimize non-specific annealing, a touchdown PCR program was used. DNA amplification was carried out in a Dyad Peltier thermal cycler $^{\odot}$ (MJ Research Inc., USA), with initial $30 \mathrm{~s}$ of DNA denaturation and polymerase activation step at $98{ }^{\circ} \mathrm{C}$, followed by 10 cycles of $5 \mathrm{~s}$ denaturation at $98{ }^{\circ} \mathrm{C}, 5 \mathrm{~s}$ annealing decreasing from 67 to $57{ }^{\circ} \mathrm{C}$ at $1{ }^{\circ} \mathrm{C}$ per cycle, $7 \mathrm{~s}$ extension at $72{ }^{\circ} \mathrm{C} ; 40$ further cycles of $5 \mathrm{~s}$ denaturation at $98{ }^{\circ} \mathrm{C}, 5 \mathrm{~s}$ annealing at $57{ }^{\circ} \mathrm{C}$ and $7 \mathrm{~s}$ extension at $72{ }^{\circ} \mathrm{C}$; and a final $1 \mathrm{~min}$ extension at $72{ }^{\circ} \mathrm{C}$

\section{Reverse line blotting (RLB)}

After amplification, $10 \mu \mathrm{l}$ of all three PCR products obtained from each individual DNA sample were mixed with $130 \mu \mathrm{l}$ of $2 x S S P E / 0.1 \%$ SDS buffer to a total volume of $160 \mu \mathrm{l}$. For each positive and negative controls $10 \mu \mathrm{l}$ of their respective PCR products were diluted in $150 \mu \mathrm{l}$ of $2 \mathrm{xSSPE} / 0.1 \%$ SDS buffer, for a total of 9 controls (i.e. 3 per each PCR) (see Fig. 2a, b).

Once prepared, samples were then heated at $100{ }^{\circ} \mathrm{C}$ for $10 \mathrm{~min}$ and cooled rapidly on ice. After cooling down, samples were centrifuged for 30 s at $11,000 \times g$ in a pre-chilled centrifuge at $4{ }^{\circ} \mathrm{C}$. Afterwards, $160 \mu \mathrm{l}$ of each sample and control preparation was loaded onto a Biodyne $\mathrm{C}$ blotting membrane (Pall Biosupport, Ann Arbor, Mich.), using a Miniblotter MN45 (Immunetics, MA, USA), on which catch-all and species-specific oligonucleotide probes (working concentration: $400 \mu \mathrm{M}$ ) containing a $\mathrm{N}$-terminal $\mathrm{N}$-(trifluoroacetamidohexyl-cyanoethyle, $N, N$-diisopropyl phosphoramidite [TFA])-C6 amino liker (Eurogentec, the Netherlands) were covalently linked as previously described [24].

The sequences of the nucleotide probes employed are reported in Table 2, enabling the simultaneous screening of each sample for up to five different genera and 12 species of tick-borne microorganisms. After loading them on the RLB membrane, samples were allowed to hybridize for one hour at $42{ }^{\circ} \mathrm{C}$. Afterwards, samples were removed using aspiration and stringent washing was carried out to remove unbound PCR product as described elsewhere [24] with the modification that the first two washing steps were performed at $50{ }^{\circ} \mathrm{C}$ for 10 min to remove false annealed PCR products. Hybridized PCR products were detected by chemiluminescence reactions, using ECL reagents (Amersham, UK) after the labeling of biotin with streptavidin horseradish peroxidase. Finally reactions were visualized using ECL hyperfilm films (Amersham, UK). Development of the ECL hyperfilm was carried out with the use of an X-ray developer (Protec GmbH, Germany).

\section{DNA purification and sequencing}

To further ascertain species identity, samples hybridizing only with a catch-all probe were subjected to DNA purification using the QIAquick Gel Extraction Kit (Qiagen $\mathrm{GmbH}$ ) and single read sequencing via a Sanger ABI 3730xl (GATC Biotech, Germany).

Sequence inspection, cleaning and alignment were conducted manually using Bioedit (version 7.0.5.2) [33]. Sequences were then identified with the use of the Basic Local Alignment Search Tool (BLAST) (NCBI Blastn). Selected sequences amongst those obtained were deposited in GenBank on 3 December 2013.

\section{Statistical analysis}

Prevalence of infected animals, single and multiple infections, and of each tick-borne microorganism were calculated with the R software (http://www.R-project.org) the 'survey' package, using the exact binomial $95 \%$ confidence interval (CI) and after weighting according to the reciprocal of the sample size of each village. Chi-square test in the WinPepi software was used to test the null hypothesis for significant difference between age classes (i.e. calves, juveniles and adults) with regards to overall and each individual pathogen's infection. $P$ values lower 0.05 were considered as statistically significant. 


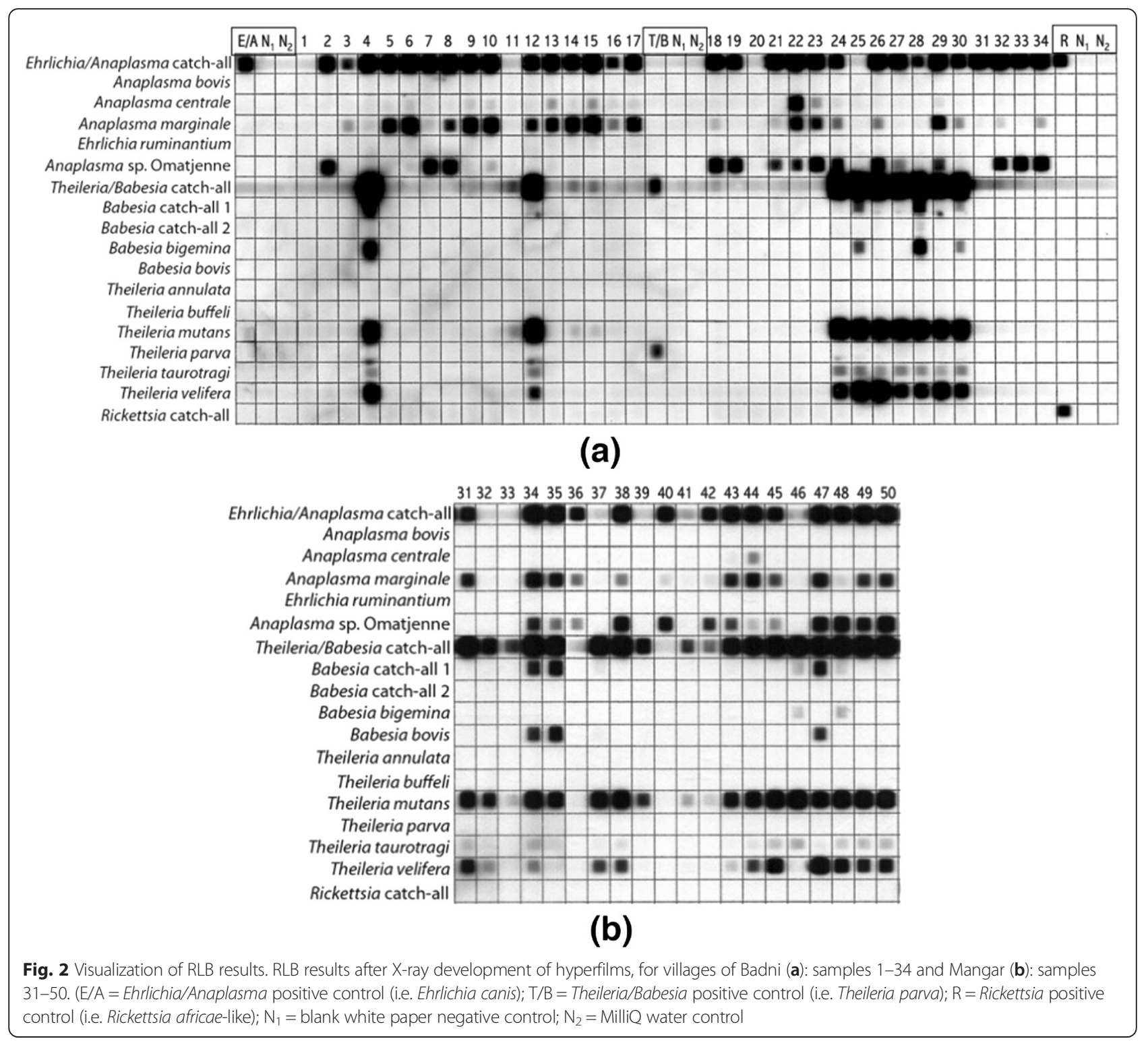

Frequency of combinations of co-infective tick-borne pathogens were calculated by normal counts according to age classes. Moreover the statistical likelihood of all possible infection patterns detectable in this study was assessed through the association screening approach [34], considering the three age classes identified (i.e. calves, juveniles and adults) altogether. Briefly, the association screening approach is a test based on a simulated theoretical distribution of a statistic and its associated confidence interval, under the null hypothesis HO that infection patterns (i.e. parasite associations or single infections) are random. In the case of this study, the occurrence (i.e. counts) of all possible combination of parasites or single infections, was theoretically simulated, with each infection pattern (either single or type of multiple infections) being exclusive of one another. The 'envelope ()' function from the 'boot' package in the $\mathrm{R}$ software (http://www.R-project.org) was used to estimate the $95 \%$ confidence envelope for the combination count distribution profile that includes all possible infection patterns. A global test based on the $95 \%$ confidence envelope was first run. When $\mathrm{H}_{0}$ was rejected, the local tests based on the number of possible parasite combinations confidence intervals were performed.

For all statistical tests employed, $P$-values $<0.05$ were considered as statistically significant.

\section{Results}

Overall infection rates

561/704 cattle (82.6 \%, 95 \% CI: 79.2-85.9 \%) were found infected by at least one tick-borne microorganism (see Table 3). 
Table 2 Genus- and species-specific probes employed for reverse line blotting

\begin{tabular}{|c|c|c|c|c|}
\hline & Tick-borne Microorganism's Genera/Species & Probe Sequence (from 5'-3') & $\operatorname{Tm}^{*}\left({ }^{\circ} \mathrm{C}\right)$ & Reference \\
\hline 1 & Ehrlichia/Anaplasma catch-all & GGGGGAAAGATTATCGCTA & 58 & {$[22]$} \\
\hline 2 & Anaplasma bovis & GTAGCTTGCTATG(A/G)GAACA & $56-58$ & {$[20]$} \\
\hline 3 & Anaplasma centrale & TCGAACGGACCATACGC & 61 & {$[22]$} \\
\hline 4 & Anaplasma marginale & GACCGTATACGCAGCTTG & 59 & {$[22]$} \\
\hline 5 & Ehrlichia ruminantium & AGTATCTGTTAGTGGCAG & 54 & {$[22]$} \\
\hline 6 & Anaplasma sp. (Omatjenne) & CGGATTITTATCATAGCTTGC & 57 & {$[22]$} \\
\hline 7 & Theileria/Babesia catch-all & TAATGGTTAATAGGA(A/G)C(A/G)GTTG & $55-59$ & {$[25]$} \\
\hline 8 & Babesia catch-all 1 & ATTAGAGTGTTCAAGCAGAC & 57 & Nijhof (unpublished) \\
\hline 9 & Babesia catch-all 2 & ACTAGAGTGTTTCAAACAGGC & 60 & Nijhof (unpublished) \\
\hline 10 & Babesia bigemina & CGTTITTCCCTITGTTGG & 58 & {$[24]$} \\
\hline 11 & Babesia bovis & CAGGTTTCGCCTGTATAATTGAG & 61 & {$[24]$} \\
\hline 12 & Theileria annulata & CCTCTGGGGTCTGTGCA & 62 & {$[20]$} \\
\hline 13 & Theileria buffeli & GGCTTATTTCGG(A/T)TTGATTT & $56-57$ & {$[24]$} \\
\hline 14 & Theileria mutans & CTTGCGTCTCCGAATGTT & 59 & {$[24]$} \\
\hline 15 & Theileria parva & GGACGGAGTTCGCTITG & 60 & {$[26]$} \\
\hline 16 & Theileria taurotragi & TCTTGGCACGTGGCTITT & 62 & {$[24]$} \\
\hline 17 & Theileria velifera & ССTATTCTCCTTTACGAGT & 54 & {$[24]$} \\
\hline 18 & Rickettsia catch-all & TTAGAAATAAAAGCTAATACCG & 54 & {$[27]$} \\
\hline
\end{tabular}

${ }^{*} \mathrm{Tm}=$ melting temperature

\section{Microorganisms' prevalence}

Theileria mutans was the most prevalent microorganism ( $n=435 / 704,95 \%$ CI: 62.1-70.4\%), followed by Theileria velifera $(n=348 / 704,95 \%$ CI: 47.9-56.9\%), Theileria taurotragi ( $n=260 / 704,95 \%$ CI: 35.1-43.9 \%), Anaplasma marginale $(n=268 / 704,95 \%$ CI: $34.8-$ $43.5 \%)$, Anaplasma sp. (Omatjenne) ( $n=239 / 704,95 \%$ CI: 30.5-38.9\%), Babesia bigemina ( $n=57 / 704,95 \%$ CI: 5.6-10.2\%), Anaplasma centrale ( $n=57 / 704,95 \%$ CI: 4.2-8.3 \%), Ehrlichia/Anaplasma spp. ( $n=27 / 704,95 \%$ CI: 2.1-5.7 \%), Rickettsia spp. ( $n=19 / 704,95$ \% CI: $1.7-$ $5.2 \%)$, Babesia bovis ( $n=16 / 704,95 \%$ CI: 1.0-2.9 \%),

Table 3 Cattle screened and found infected for any tick-borne microorganism in the study area

\begin{tabular}{llllll}
\hline Village name & $\begin{array}{l}\text { Total cattle } \\
\text { population }\end{array}$ & \multicolumn{4}{l}{ Animals sampled (Infected) } \\
\cline { 3 - 6 } & Calves & Juveniles & Adults & Totals \\
\hline Ampang West & 790 & 0 & $33(28)$ & $47(38)$ & $80(66)$ \\
Badni & 383 & $4(3)$ & $20(18)$ & $56(46)$ & $80(67)$ \\
Bokkos & 2142 & $6(6)$ & $25(22)$ & $49(42)$ & $80(70)$ \\
Daffo & 2933 & $4(1)$ & $17(12)$ & $51(45)$ & $72(58)$ \\
Hurti & 1011 & $2(1)$ & $9(7)$ & $69(64)$ & $80(72)$ \\
Maiyanga & 2543 & $6(5)$ & $32(31)$ & $42(32)$ & $80(68)$ \\
Mangar & 1373 & $5(3)$ & $29(25)$ & $46(44)$ & $80(72)$ \\
Ruff & 154 & $5(1)$ & $18(14)$ & $49(32)$ & $72(47)$ \\
Tambes & 854 & $11(6)$ & $1(0)$ & $68(35)$ & $80(41)$ \\
Total & 12,183 & $43(26)$ & $184(158)$ & $477(378)$ & $704(561)$ \\
\hline
\end{tabular}

Ehrlichia ruminantium ( $n=8 / 704,95 \%$ CI: 0.2-1.9\%) (see also Fig. 3).

Theileria mutans, T. velifera, T. taurotragi, A. marginale and Anaplasma sp. (Omatjenne) were significantly $(P<0.0001)$ more prevalent (above at least $30 \%)$, than A. centrale, B. bigemina, A. platys, Rickettsia spp., $B$. bovis and E. ruminantium (below $10 \%$ in prevalence).

Sequenced Ehrlichia/Anaplasma catch-all 16S rRNA positive samples were found 99-100\% similar with Anaplasma platys (Accession No.: KC989957.1, KF360842.1, KF576217.1) $(n=9)$. Sequenced Rickettsia spp. 16S rRNA gene fragments were found $100 \%$ similar with spotted fever group (SFG) rickettsiae (i.e. Rickettsia massiliae, Accession No.: NR074486.1) $(n=3)$.

In all villages, the five most prevalent microorganisms were represented by $T$. mutans, $T$. velifera, $T$. taurotragi, A. marginale and Anaplasma sp. (Omatjenne). Out of the 11 microorganisms detected, only three were not found in all villages. $R$. massiliae $16 \mathrm{~S}$ rDNA was detected in seven villages (Ampang West, Bokkos, Daffo, Maiyanga, Mangar, Ruff and Tambes), B. bovis in four villages (Bokkos, Hurti, Mangar and Tambes) and E. ruminantium in only two villages (Ampang West and Bokkos).

\section{Co-infections}

465/704 (69.6 \%, 95 \% CI: 65.5-73.6\%) cattle were positive for two or more microorganisms simultaneously. Overall 77 different combinations of microorganisms 


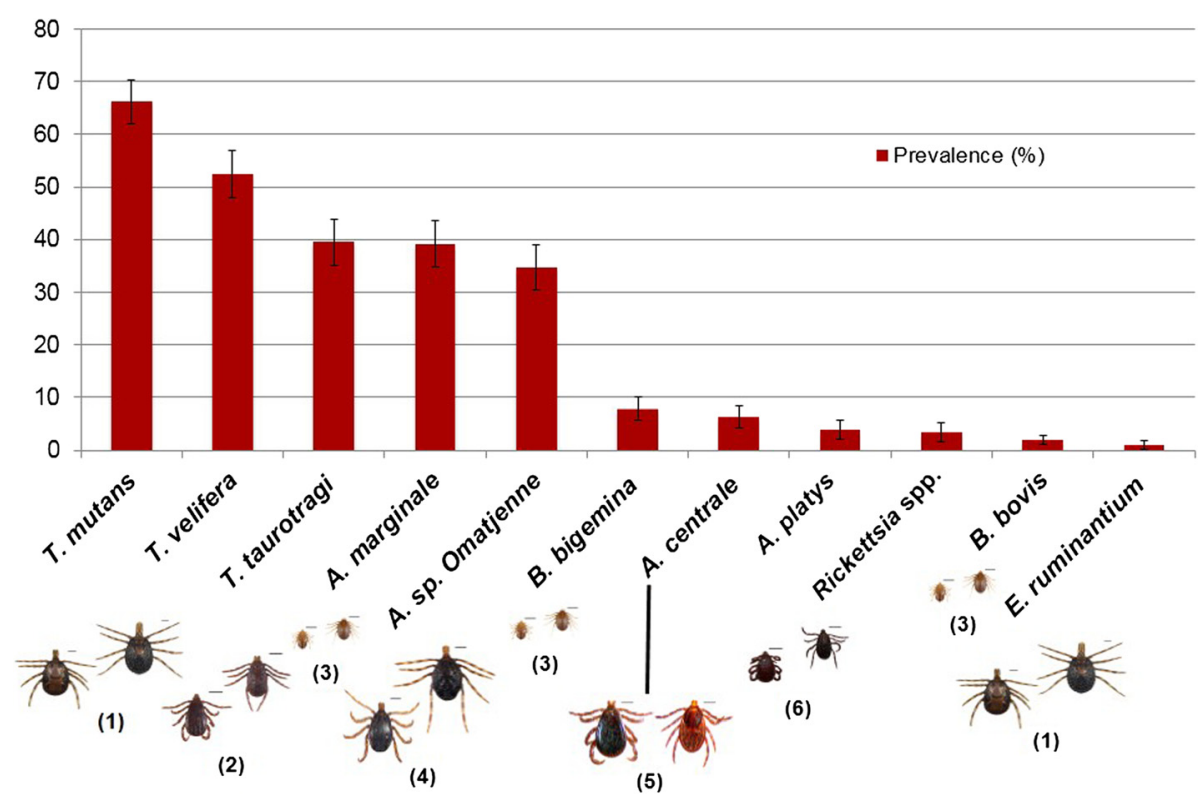

Fig. 3 Prevalence (\%) of each tick-borne pathogen in relation to its primary competent vector ticks. (1) = A. variegatum for T. mutans, T. velifera and E. ruminantium; (2) = Rhipicephalus spp. for T. taurotragi; (3) = Rhipicephalus (Boophilus) spp. for A. marginale, B. bigemina, A. centrale and B. bovis; (4) = H. truncatum, presumably, for Anaplasma sp. (Omatjenne); (5) $=$ Rh. simus for $A$. marginale and $A$. centrale; (6) $=$ Rh. sanguineus (sensu lato) for A. platys and Rickettsia spp. (R. massiliae according to $16 \mathrm{~S}$ rDNA sequencing). Vector competence for the transmission of T. taurotragi, Anaplasma sp. (Omatjenne), A. platys, R. massiliae; Anaplasma spp. in Rh. simus Group and B. bovis in Rh. (Bo.) spp. in Nigeria needs to be further confirmed

were found. The largest variety of co-infections was recorded in adult cattle $(n=58)$, followed by juveniles $(n=$ $43)$ and calves $(n=11)$ (see also Additional file 1$)$.

On the whole, the most frequent combinations included three (i.e. T. mutans $+T$. taurotragi $+T$. velifera) to five co-infective species (i.e. A. marginale + Anaplasma sp. (Omatjenne) $+T$. mutans $+T$. taurotragi $+T$. velifera) (Table 4 and Additional file 1). B. bigemina was never found infecting the same host together with $B$. bovis.

\section{Single infections}

Ninety-six single infections were detected, amongst 561 positive cases (13\%, $95 \%$ CI: 10.3-15.6\%), of which nine were in calves (34.6 \% of positive animals), 27 in juveniles (17\% of positive animals) and 60 in adult cattle (15.8\% of positive animals). Cases of single infections were mostly represented by $T$. mutans $(n=32)$, found in $7 / 9$ villages, $A$. sp. Omatjenne $(n=30)$ and $A$. marginale $(n=22)$, detected in all study villages, followed by Rickettsia spp. $(n=6)$, A. platys $(n=2), B$. bigemina $(n=2)$, B. bovis $(n=1)$, and T. velifera $(n=1)$.

Examining statistically all infection patterns detected according to the association screening approach [34], single infections by Anaplasma sp. (Omatjenne) $(n=30 /$ 239, $12.5 \%$ of cases of infection with Anaplasma sp. (Omatjenne)) and by Rickettsia spp. ( $n=6 / 19,31.6 \%$ of total number of infections with Rickettsia spp.) were found to be significantly likely $(P<0.001)$ to occur in this study (see Table 4).

\section{Age-class infections}

On the whole, calves were significantly less infected than juveniles $\left(\chi^{2}=12.759, d f=2\right.$, OR $\left.=0.252, P=0.001\right)$ and adult cattle $\left(\chi^{2}=7.096, d f=2, \mathrm{OR}=0.401, P=0.02\right)$, whereas no statistically significant difference was detected between juveniles and adults $\left(\chi^{2}=3.980, d f=2\right.$, $\mathrm{OR}=1.592, P=0.138)$. When reviewing each individual tick-borne infection, calves were significantly less infected than both juveniles and adults with regards to $T$. mutans $\left(\chi^{2}=24.449, d f=2, \mathrm{OR}=5.756, P<0.0001\right.$ and $X^{2}=18.868, d f=2$, OR $=4.225, P<0.0001$, respectively), T. velifera $\left(\chi^{2}=22.728, d f=2, \mathrm{OR}=7.277, P<0.0001\right.$ and $\chi^{2}=29.616, d f=2, \mathrm{OR}=8.370, P<0.0001$, respectively) and T. taurotragi $\left(\chi^{2}=16.381, d f=2, \mathrm{OR}=5.592, P<\right.$ 0.0001 and $\chi^{2}=13.248, d f=2, \mathrm{OR}=4.484, P=0.001$, respectively) infections, while no significant difference was recorded when comparing juvenile with adult cattle, for $T$. mutans $\left(\chi^{2}=2.838, d f=2\right.$, OR $\left.=0.734, P=0.3\right) ; T$. velifera $\left(\chi^{2}=0.65, d f=2, \mathrm{OR}=1.150, P=1\right)$ and $T$. taurotragi $\left(\chi^{2}\right.$ $=1.554, d f=2, \mathrm{OR}=0.802, P=0.6)$. In addition, calves were significantly less infected than juveniles $\left(\chi^{2}=7.322\right.$, $d f=2$, OR $=2.877, P=0.02)$, but not than adults $\left(\chi^{2}=\right.$ 4.183, $d f=2$, OR $=2.167, P=0.1$ ), for Anaplasma sp. (Omatjenne). Furthermore, both calves and juveniles were significantly more infected by $B$. bigemina than adults $\left(\chi^{2}\right.$ 
Table 4 Statistically significant most and least likely infection patterns of the study

\begin{tabular}{lll}
\hline Infection pattern & $\begin{array}{l}\text { No. of } \\
\text { observations }\end{array}$ & $\begin{array}{l}95 \% \text { Confidence } \\
\text { interval }\end{array}$ \\
\hline (A) Significantly most likely infection & pattern $(P<0.001)$ \\
Tm $+\mathrm{Tt}+\mathrm{Tv}$ & 79 & $10-44$ \\
$\mathrm{Am}+\mathrm{AspO}+\mathrm{Tm}+\mathrm{Tt}+\mathrm{Tv}$ & 42 & $0-20$ \\
$\mathrm{Am}+\mathrm{AspO}$ & 33 & $1-22$ \\
$\mathrm{AspO}$ & 30 & $3-28$ \\
$\mathrm{Am}+\mathrm{AspO}+\mathrm{Tm}+\mathrm{Tt}+\mathrm{Tv}+\mathrm{Bb}$ & 12 & $0-5$ \\
$\mathrm{Ap}+\mathrm{Tm}+\mathrm{Tt}+\mathrm{Tv}$ & 12 & $0-7$ \\
$\mathrm{Am}+\mathrm{Ac}+\mathrm{AspO}+\mathrm{Tm}+\mathrm{Tt}+\mathrm{Tv}$ & 10 & $0-5$ \\
$\mathrm{Am}+\mathrm{Ac}$ & 8 & $0-7$ \\
$\mathrm{Am}+\mathrm{Ac}+\mathrm{AspO}$ & 7 & $0-6$ \\
$\mathrm{R}$ & 6 & $0-5$
\end{tabular}

(B) Significantly least likely infection patterns $(P<0.001)$

$\begin{array}{lll}A m+T m & 7 & 11-46 \\ T m+T t & 6 & 8-44 \\ A s p O+T m & 5 & 6-38 \\ T v & 1 & 10-47 \\ A m+T m+T t & 1 & 4-32 \\ A m+T v & 0 & 4-30 \\ A s p O+T v & 0 & 3-33 \\ T t & 0 & 3-31 \\ T t+T v & 0 & 2-30 \\ A m+T t+T v & 0 & 1-24 \\ A m+T t & 0 & 1-23\end{array}$

Abbreviations: Ac, Anaplasma centrale; Am, Anaplasma marginale; $A p$, Anaplasma platys; AspO, Anaplasma sp. (Omatjenne); Er, Ehrlichia ruminantium; $R$, Rickettsia spp. (R. massiliae according to $16 \mathrm{~S}$ rDNA sequencing); Bb, Babesia bigemina; Tm, Theileria mutans; Tt, Theileria taurotragi; $T v$, Theileria velifera

$=17.947, d f=2, \mathrm{OR}=0.147, P<0.0001$ and $\chi^{2}=10.915, d f$ $=2, \mathrm{OR}=0.355, P=0.003$, respectively). No E. ruminantium infection was detected in calves (see also Fig. 4).

\section{Discussion}

The present study aimed to ascertain by molecular means the occurrence of tick-borne microorganisms of veterinary and zoonotic importance in cattle from an area of North-Central Nigeria, where no acaricide-based vector control is usually undertaken, in spite of the presence of a great species diversity and high burdens of ticks on cattle [6]. To do so, an RLB-based method enabling to test each sample against a panel of genus- (i.e. 'catch-all') and species-specific probes was employed (Table 2; Fig. 2a, b).

In total, 704 cattle were included in this study, the greater number of adult rather than younger cattle, among those sampled, reflects the age composition of
Fulani herds, with at least $60 \%$ of animals being adult [13, 35].

On the whole, the study disclosed high infection rates (i.e. $82.6 \%$ ) in the overall cattle population, with a broad diversity of pathogens detected, in presence of a complex scenario of frequent multiple infections. This study established the existence of a stark dichotomy in the occurrence of tick-borne pathogens, with five microorganisms, i.e. T. mutans, $T$. velifera, T. taurotragi, $A$. marginale and Anaplasma sp. (Omatjenne) being significantly $(P<0.0001)$ more prevalent (above at least $30 \%)$, than each of $A$. centrale, B. bigemina, A. platys, Rickettsia spp., B. bovis and E. ruminantium (below $10 \%$ in prevalence) (Fig. 3).

The occurrence of Anaplasma sp. (Omatjenne)e and A. platys is novel for cattle from Nigeria, and so is that of $T$. taurotragi for cattle from West Africa. Moreover, thus far, $R$. massiliae had never been found infecting livestock on a global scale.

Theileria mutans and T. velifera were the two most prevalent microorganisms (i.e. 66.3 and $52.4 \%$, respectively) in the study area. These two mildly pathogenic Theileria species have long been recognised as the only two Theileria species present in Nigeria [12, 15]. They are both transmitted by Amblyomma variegatum [36, 37] (Fig. 3), endemically present in the whole of Nigeria [5] including the Plateau State [6]. Although in different proportions, these two Theileria species were recorded in all age classes, being the first and second most prevalent microorganism recorded in both adults and juveniles and the second (i.e. T. mutans) and fourth most prevalent ( $T$. velifera) microorganism detected in calves. This suggests an early exposure of cattle on the Plateau to these piroplasms, due to early infestations with $A$. variegatum [6].

Theileria taurotragi was the third most frequently detected microorganism in the present study (39.5\%). Primarily associated with elands [Taurotragus (Tragelaphus) oryx (Pallas, 1766)] in East and Southern Africa, to date it has been recorded in cattle from East, Central and Southern SSA [38]. This Theileria species is known to be transmitted naturally by Rhipicephalus appendiculatus and Rhipicephalus zambesiensis and, experimentally, by Rhipicephalus pulchellus and Rhipicephalus evertsi [38]. Neither the original wildlife host of this pathogen, or the aforementioned tick species, are known to be found in North-Central Nigeria, with Rh. evertsi evertsi being retrieved only more southward in the country [8]. Therefore, an exchange of competent multiple-host ticks from infected antelopes similar to T. orynx to cattle is the hypothesis here raised to explain the presence of T. taurotragi in cattle in Nigeria.

Anaplasma marginale was the fourth most prevalent pathogen detected in this study at $39.1 \%$. The present 


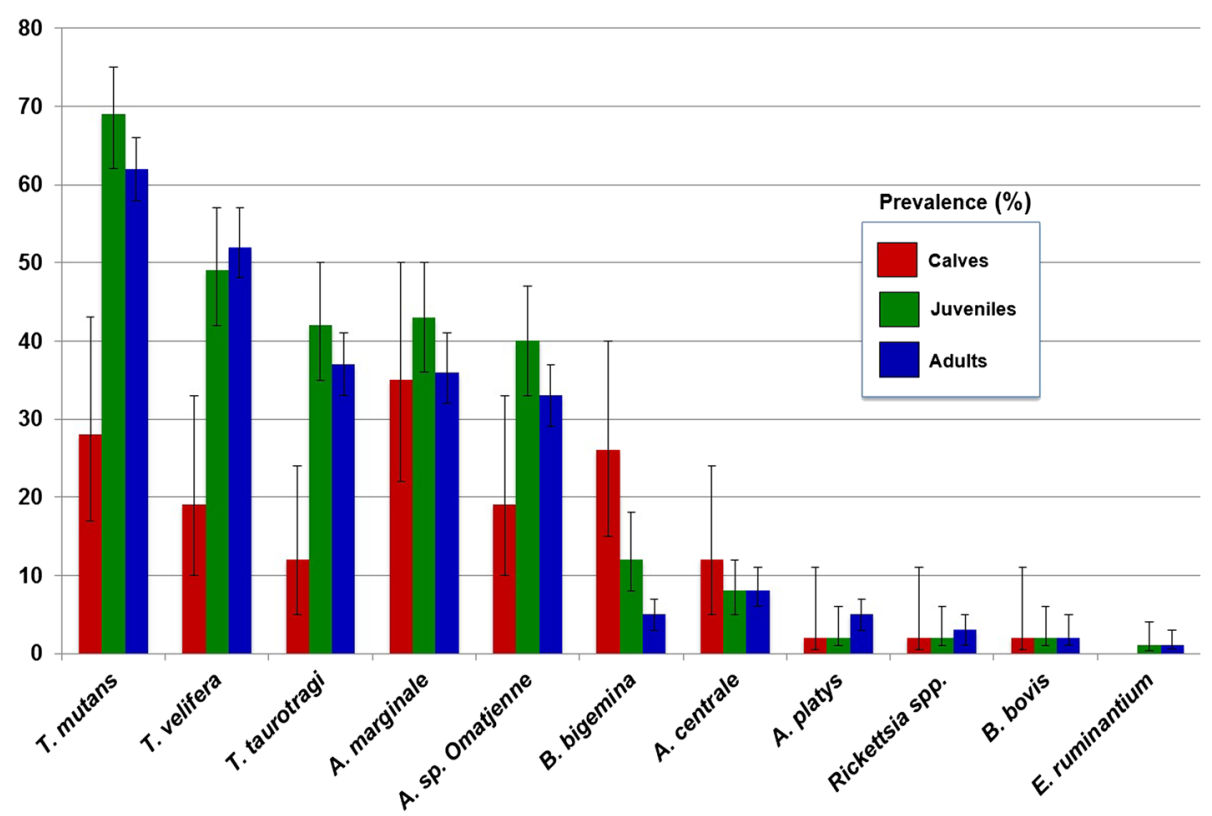

Fig. 4 Prevalence (\%) of each tick-borne pathogen detected, compared according to age classes. Error bars indicate $95 \% \mathrm{Cl}$, while asterisks indicate statistically significant difference between age classes. Calves were significantly less infected than both juveniles and adults for $T$. mutans $(P<0.0001$ in both cases), T. velifera $(P<0.0001$ in both cases) and T. taurotragi $(P<0.0001$ and $P=0.001)$ infections. Calves were significantly less infected than juveniles $(P=0.02)$ with respect to Anaplasma sp. (Omatjenne) infection. Both calves and juveniles were significantly more infected than adult cattle $(P<0.0001$ and $P=0.003)$ for $B$. bigemina infection

prevalence is comparable to that of $34 \%$ found in the late 1970s by serological rapid card agglutination test in a similarly sized cattle population $(n=573)$ from Northern Nigeria [18]. Similarly, another serological investigation on 50 herds from ten states in Northern Nigeria disclosed a prevalence of $79.4 \%$ of A. marginale [19]. These results are consistent with the present finding, considering that the use of the RLB can detect an active infection or a carrier status, but not seroconversion, detectable by means of serology.

The prevalence of $A$. marginale recorded in this study was similar in all age classes (Fig. 4). In particular, $A$. marginale was the most prevalent pathogen detected in calves, suggesting that this microorganism infects young stock early in their lives or possibly also during intrauterinal development [39].

Persistently infecting cattle that serve as long-term reservoirs [39], A. marginale can be transmitted not only via the Rhipicephalus ticks highly prevalent in this region [6], but also via mechanical vectors, such as bloodsucking flies (Stomoxys spp., Tabanus spp.) [39], also found in this part of Nigeria [40]. Thus, calves found positive in this study seemingly represented active infections by $A$. marginale, while older cattle can be considered as chronically infected carriers.

This study provides the confirmation of the presence of A. centrale in North-Central Nigeria, with a prevalence of $6.3 \%$. Considering the richness of competent vectors (i.e. Rh. annulatus, Rh. decoloratus and $R h$. simus Group) of this microorganism in the study area [6], one may speculate on the lower capacity of this species, compared to $A$. marginale, to disseminate within herds. Moreover, as an endemically stable setting for Anaplasma spp. is usually characterised by high infection rates in adult cattle, due to their carrier status, the rather homogenous prevalence detected for $A$. centrale in this study across all age classes (see also Fig. 4) may be suggestive of the existence of an extent of epidemiological 'instability' for this microorganism. This situation may favour the onset of sporadic episodes of acute anaplasmosis in the indigenous cattle population.

Babesia bigemina and B. bovis were documented to occur in this area, both with a prevalence below 10 (i.e. 7.9 and $2.0 \%$, respectively, Fig. 3). A previous serological investigation (i.e. IFAT) carried out in 50 herds from ten states in Northern Nigeria had disclosed a prevalence of 29.4 and $14.1 \%$ for B. bigemina and B. bovis respectively [19], consistent with the present findings.

Babesia bigemina was known to be endemic in most of Nigeria already by the early 1920s, with cattle becoming infected in early life without showing apparent disease, then acquiring life-long immunity after recovery, due to repeated challenge by $R h$. decoloratus ticks [10], currently the most prevalent tick species in the study area during the wet season [6]. This would explain the overall low prevalence $(7.9 \%)$ recorded in this study for 
B. bigemina, a finding that may be influenced by the lower infection rates recorded in the more numerous adults. Here, in fact, calves (25.6 \%) and juveniles (12.5\%) were found significantly more infected than adult cattle (4.8\%) $(P<0.0001$ and $P=0.003$, respectively) (Fig. 4). It is likely that adult cattle that tested negative in this study included large proportions of animals that had successfully recovered active infections. Conversely, positive calves and juvenile cattle may be those individuals in which passive and innate immunity declined, thus developing detectable parasitaemia after exposure to sufficiently high challenge by infective $R h$. decoloratus ticks.

The present study confirms the presence of $B$. bovis in North-Central Nigeria. Since the first report in 1956 in the Plateau province [10], several other studies had reported the presence of $B$. bovis in cattle in Nigeria relying on morphological $[10,11,14]$ and serological (i.e. IFAT) characterization [16].

In the present study, B. bovis was found in a rather lower prevalence $(2.0 \%)$ than that of $B$. bigemina (7.9 \%), especially in calves $(n=1 / 43$ and $n=11 / 43$ respectively). This could be explained considering that tick infection rates are usually higher with $B$. bigemina $(0.23 \%)$ than in B. bovis $(0.04 \%)$ [41], with a consequent slower rate of transmission of the latter to cattle. This would also suggest that, in an area where both species are present, endemic stability would be more likely to establish for B. bigemina [42]. Moreover, the lower prevalence of $B$. bovis compared to $B$. bigemina could also be explained by the seemingly lower parasitaemia levels occurring in adult carrier animals [24].

While $R h$. decoloratus is known as vector for B. bigemina in Nigeria [43], the vector capacity for B. bovis in this country has not yet been fully clarified. A tick species that could plausibly be involved in the transmission of $B$. bovis in Nigeria is Rh. annulatus, known for being vector of this piroplasm in other geographic areas (e.g. Southern Europe and Northern Africa) [42], and well represented in the Plateau State [6]. Rhipicephalus geigyi was also found to harbour kinetes associated for shape and size with B. bovis [44]. If this was confirmed also for North-Central Nigeria, it would help explain the lower prevalence of $B$. bovis compared to B. bigemina, considering that $R h$. geigyi is not as prevalent $(7.6 \%)$ as $R h$. decoloratus (41.4\%) and Rh. annulatus (15.4\%) in the Nigerian Plateau State [6].

The very low overall prevalence (i.e. $1.1 \%$ ) detected in this study for E. ruminantium can be attributed to the biology of its infection. After recovery from the acute phase, low numbers of this microorganism can still reproduce in the endothelial cells of the capillaries, being released only periodically into the bloodstream [45]. The low prevalence recorded may also be related to the rigid control practice carried out traditionally by the local Fulani pastoralists, seemingly targeting specifically $A$. variegatum adults [5]. Undoubtedly, though, the manual 'de-ticking' of the Fulani, did not affect the detectability of $T$. mutans and T. velifera, also transmitted by $A$. variegatum $[36,37]$. These piroplasms are nevertheless characterised by higher and longer-lasting parasitaemia in carrier animals [46] compared to $E$. ruminantium [47].

Anaplasma sp. (Omatjenne) was the fifth most frequently detected microorganim (34.7\%) in this study. Recently, this species was detected also in dogs sampled from this area of Nigeria [48], further confirming the circulation of this microorganism in this country.

Genetically close to E. ruminantium, this poorly known Anaplasma species was initially isolated in Hyalomma truncatum ticks collected from apparently healthy cattle in Namibia [49]. This tick species in known to occur in this study area [6]. Initially thought to be apathogenic in cattle, studies have also showed the association of Anaplasma sp. (Omatjenne) with 'heartwater' (cowdriosis)-like syndrome in sheep under experimental conditions [49]. Would the involvement of $A$. sp. Omatjenne in the aetiology of cowdriosis be confirmed, the low prevalence detected in the present study for $E$. ruminantium (1.1\%) would also result as more plausible, considering that this TBD was considered to be endemic in Nigeria $[10,11]$.

In this study, $A$. platys was found infecting cattle with a prevalence of $3.9 \%$; the presence of this rickettsia being documented in all the study villages. This widespread distribution of the infection suggests more an established host-pathogen relationship rather than a merely incidental finding.

Anaplasma platys is a thrombocytotropic bacterium usually infecting dogs, in which it is responsible for causing a syndrome known as canine infectious cyclic thrombocytopenia [50]. Recently, A. platys infections were molecularly detected in cattle in Sardinia, Italy [51], sheep in Senegal [52] and humans in the Americas $[53,54]$; the pathogenic role of this microorganism in these hosts remains yet to be understood. The presence of this rickettsia was documented in dogs from the same region in Nigeria, with a prevalence of $6.6 \%$ [55]. Evidence suggests that $A$. platys is vectored by Rhipicephalus sanguineus sensu lato [56]. This tick, whose preferential host is represented by dog [57], has also been found, though in low burdens, in cattle in this part of Nigeria [6].

The finding of $100 \%$ similarity of Rickettsia spp. positive amplicons with $R$. massiliae $16 \mathrm{~S}$ rDNA is suggestive of the occurrence of this SFG rickettsia in the study area. Future PCR and sequencing-based studies targeting SFG-specific genes (e.g. ompA and $o m p B$ ) would be advisable to further confirm the occurrence of this pathogen in the Plateau State. Initially isolated in 1990 from 
Rhipicephalus turanicus and Rh. sanguineus (sensu lato) [58], $R$. massiliae is one of the most widely distributed SFG rickettsiae, described so far in all five continents [59]. The presence of this microorganism's DNA was recently documented in questing $R h$. evertsi ticks, collected from the vegetation in the South-western part of Nigeria [8]. In other SSA countries (i.e. Central African Republic, Guinea, Ivory Coast and Mali), R. massiliae was detected in several Rhipicephalus spp. ticks collected from cattle (e.g. Rh. guilhoni, Rh. lunulatus, Rh. muhsamae, Rh. senegalensis and Rh. sulcatus) [59, 60]; most of these tick species were found in this study area [6], thus representing a potential source of infection for the positive animals of the study. Would the presence of $R$. massiliae be confirmed also for the local tick fauna of Rhipicephalinae, it would raise public health concern, considering the pathogenicity of this species to humans [59].

On the whole, calves were significantly less infected than both juvenile $(p=0.001)$ and adult cattle $(P=0.02)$. This is in line with the concept of 'inverse age resistance', consisting in the higher resistance or tolerance to an infection of young cattle compared to adults in an endemic area for a certain TBD [61]. This is consistent with several other studies carried out in SSA, including North-Central Nigeria, where a lower proportion of infection (14.5\%) was detected in younger cattle compared to adults (36.3\%), although an index of quantification of age is not given [14].

The finding in the present study suggests that cattle are more likely challenged by the infection between six months and two years, as a possible result of the declining of a previous colostral and perhaps also innate immunity [47]. Conversely, the rather similar prevalence recorded in juvenile and adult cattle (39.7 and $33.1 \%$, respectively), suggests the persistence of a carrier status in older animals. Moreover, the lower infection rates in calves can be attributed to their lower tick burdens compared to juvenile and adult cattle [6].

The reported combinations of co-infective agents are suggestive of the absence of competition, or antagonist effect, among the three Theileria species altogether (i.e. T. mutans, T. velifera and T. taurotragi); these and A. marginale and $A$. sp. Omatjenne; between the latter two species; among the five aforementioned microorganisms, with or without B. bigemina or A. centrale (Table 4 and Additional file 1).

Anaplasma marginale and Anaplasma sp. (Omatjenne), the fourth and fifth most frequently detected microorganisms, were found to be likely $(P<0.001)$ associated with the three theilerias (i.e. T. mutans, $T$. velifera and $T$. taurotragi), only if present together. This may suggest a synergism between these two co-infection patterns (i.e. A. marginale + Anaplasma sp. (Omatjenne) and $T$. mutans $+T$. taurotragi $+T$. velifera). The frequent association between $T$. mutans and T. velifera, may be related to transmissions through the same tick vector (i.e. A. variegatum) and to the fact that infections by both are characterized by durable carrier statuses [36, 37].

Theileria taurotragi was always detected in presence of other Theileria species (Additional file 1). Indeed, while the combination of all three theilerias (i.e. $T$. mutans $+T$. velifera $+T$. taurotragi) together was found to be a statistically significant type of association $(P<$ 0.001 ) (Table 4), the association of T. taurotragi with $T$. mutans (recorded in six samples only) as well as that of $T$. taurotragi with $T$. velifera (never detected in this study) were found to be statistically unlikely $(P<0.001)$ to occur in this study (Table 4). This suggests a possible favouring role played by $T$. mutans and $T$. velifera, together, towards the establishment of a parasitaemia by $T$. taurotragi. Some of these findings are consistent with those of another RLB-based study carried out in indigenous cattle from Kenya [62]; however, the frequent and statistically significant association observed between $A$. marginale and Anaplasma sp. (Omatjenne) was in contrast to this previous work.

In accordance with another RLB-based study in 477 cattle in Mozambique [63], no case of co-existence of the two Babesia spp. was recorded in this study; the lack of co-infections detected could be the hypothetical existence of competition between B. bigemina and B. bovis.

In this study, single infections accounted for less than $1 / 5$ of the total number of positive cases. Single infections were frequent in calves $(34.6 \%$ of positive animals), followed by juveniles (17 \%) and adult cattle (15.8\%), a finding that is in accordance with the principle of inverse age resistance aforementioned.

The large majority $(n=84 / 92,91 \%)$ of the single infections detected in this study were caused by $T$. mutans, Anaplasma sp. (Omatjenne) and A. marginale, reflecting the high prevalence of these microorganisms; and by $R$. massiliae ( $n=6 / 19,31.6 \%$ of total number of Rickettsia spp. positive cases). Considering its overall low prevalence (i.e. $3.5 \%$ ) in this study, it is possible that the detectability of Rickettsia spp. in the blood stream may be favoured by the absence of other tick-borne pathogens.

\section{Conclusions}

In conclusion, this study discloses the occurrence of numerous tick-borne pathogens of veterinary and zoonotic importance in cattle from Nigeria, in the presence of a complex scenario of multiple infections. The high prevalence and the great variety of pathogens recorded (including, amongst others, T. mutans, T. velifera, A.marginale and $B$. bigemina), poses a serious threat to the possible 
introduction of exotic taurine (i.e. B. taurus) breeds in the area.

The RLB technique employed proved to be a very sensitive tool, enabling the simultaneous detection of several microorganisms as well as the identification of pathogens not expected in this geographic area (i.e. $T$. taurotragi) and in the cattle host (i.e. A. platys and $R$. massiliae, based on $16 \mathrm{~S}$ rDNA detection). Future research endeavors may incorporate species-specific probes targeting the latter two microorganisms to allow their prompt identification via RLB.

Herein, results highlight the need to consider coinfections, as opposed to single pathogens, in rural settings of extensive grazing. In particular, these findings point out the involvement of cattle in the epidemiology of tick-borne infections pertaining to dog (i.e. A. platys) and potentially also human health (i.e. A platys and $R$. massiliae).

Future studies aiming to better understand the vectors linked to the host-microorganisms associations disclosed (i.e. T. taurotragi, Anaplasma sp. (Omatjenne), A. platys and $R$. massiliae) or confirmed (i.e. B. bovis) are also recommended. In particular, further molecular work should be warranted to confirm the occurrence of $R$. massiliae in this area, to better understand the risk of exposure for the local population handling cattle (e.g. pastoralists, veterinary and para-veterinary personnel), thus more vulnerable to tick bites.

\section{Additional file}

Additional file 1: Multiple infections by tick-borne pathogens according to age classes and overall number of animals. (PDF $19 \mathrm{~kb}$ )

\section{Competing interests}

The authors declare they have no competing interests.

\section{Authors' contributions}

$V L, K P$ and SCW conceived and designed the experiments. AOM, MT, CD, AF, $\mathrm{KP}$ and SCW conceived and designed the field survey. AOM, CD, AF and AGD collected samples in the field. VL, MW and KP performed the experiments. $V L, M T$ and $E V$ analyzed the data. $V L$ and $A M$ designed the maps of Fig. 1. SCW, KP, AGD, ACI and FJ contributed reagents, materials and analysis tools. VL, MW, KP, AOM, SCW, FJ, ACl, EV and AM wrote the manuscript. All authors read and approved the final version of the manuscript.

\section{Acknowledgements}

This study was funded by the UK's Biotechnology and Biological Sciences Research Council (BBSRC) under the 'Combating Infectious Diseases in Livestock for International Development' (CIDLID) scheme, and the European Union's Seventh Framework Program (FP7/2007-2013) under grant agreement $n^{\circ} 221948$, Integrated Control of Neglected Zoonoses (ICONZ) Authors are grateful to Dr Tim Connelley (The Roslin Institute, Edinburgh, UK) for providing Theileria parva DNA; Dr Lesley Bell-Sakyi (The Tick Cell Biobank, Pirbright, UK) and Dr Pilar Alberdi (University of Castilla-La Mancha, Spain) for providing rickettsial DNA; Dr Zorica Zivkovic (Beaphar, The Netherlands) for her kind encouragement; Dr Dennis Muhanguzi (Makerere University, Uganda) for his valuable suggestions. Dr Tim Connelley and Prof Richard Birtles (Salford
University, Manchester, UK) are also acknowledged for their valuable comments on this work.

\section{Author details}

${ }^{1}$ Division of Infection and Pathway Medicine, School of Biomedical Sciences, The University of Edinburgh, Edinburgh, UK. ${ }^{2}$ Utrecht Centre for Tick-borne Diseases, Utrecht University, Utrecht, The Netherlands. ${ }^{3}$ Nigerian Institute for Trypanosomiasis Research, VOM, Jos, Plateau, Nigeria. ${ }^{4}$ National Veterinary Research Institute, VOM, Jos, Plateau, Nigeria. ${ }^{5}$ Royal (Dick) School of Veterinary Studies, The University of Edinburgh, MidlothianEH25 9RGUK. ${ }^{6}$ Unité d'Épidémiologie Animale, Institut National de la Recherche Agronomique, Centre de recherche de, Clermont-Ferrand-Theix, France. ${ }^{7}$ Department of Veterinary Tropical Diseases, Faculty of Veterinary Medicine, University of Pretoria, Onderstepoort 0110, Pretoria, Republic of South Africa.

Received: 28 January 2016 Accepted: 11 April 2016

Published online: 18 April 2016

\section{References}

1. Jongejan F, Uilenberg G. The global importance of ticks. Parasitology. 2004; 29:S13-14.

2. CIA - the world factbook. Nigeria. People and Society. https://www.cia.gov/ library/publications/the-world-factbook/geos/ni.html. (2014) Accessed: 3 Jan 2016.

3. FAO Animal Production and Health. Agriculture and Consumer Protection Department. http://www.fao.org/ag/againfo/resources/en/glw/GLW_dens. html (2014) Accessed: 5 Aug 2014

4. Awogbade MO. Fulani pastoralism and the problems of the Nigerian veterinary service. Afr Aff. 1979;6:493-50. 1979.

5. Bayer W, Maina JA. Seasonal pattern of tick load in Bunaji cattle in the subhumid zone of Nigeria. Vet Parasitol. 1984;6:301-7.

6. Lorusso V, Picozzi K, de Bronsvoort BM, Majekodunmi A, Dongkum C, Balak $\mathrm{G}$, et al. Ixodid ticks of traditionally managed cattle in central Nigeria: where Rhipicephalus (Boophilus) microplus does not dare (yet?). Parasit Vectors. 2013;6:171.

7. Ogo NI, de Mera IG, Galindo RC, Okubanjo OO, Inuwa HM, Agbede Rl, et al. Molecular identification of tick-borne pathogens in Nigerian ticks. Vet Parasitol. 2012;187:572-7

8. Reye AL, Arinola OG, Hübschen JM, Muller CP. Pathogen prevalence in ticks collected from the vegetation and livestock in Nigeria. Appl Environ Microbiol. 2012;78:2562-8.

9. Lorusso V, Gruszka KA, Majekodunmi A, Igweh A, Welburn SC, Picozzi K. Rickettsia africae in Amblyomma variegatum ticks. Uganda and Nigeria. Emerg Infect Dis. 2013;19:1705-7.

10. Leeflang P, llemobade AA. Tick-borne diseases of domestic animals in northern Nigeria. I. Historical review, 1923-1969. Trop Anim Health Prod. 1977;9:147-52.

11. Leeflang P, Ilemobade AA. Tick-borne diseases of domestic animals in northern Nigeria. II. Research summary, 1966 to 1976. Trop Anim Health Prod. 1977:9:211-8.

12. Perié NM, Uilenberg G, Schreuder BE. Theileria mutans in Nigeria. Res Vet Sci. 1979;26:359-62.

13. Maina JA. Animal health in subumid Nigeria. In: Von K et al., editors. Livestock systems research in Nigeria's sub-humid zone. Proceedings of the Second ILCA/NAPRI Symposium. Kaduna, Nigeria: Addis Ababa: ILCA; 1986.

14. Kamani J, Baneth G, Mumcuoglu KY, Waziri NE, Eyal O, Guthmann Y, et al. Prevalence and significance of haemoparasitic infections of cattle in northcentral. Nigeria Vet World. 2010;3:445-8.

15. Saidu SN, Abdulkadir IA, Akerejola OO. Theileria mutans infection in Nigerian cattle. Trop Anim Health Prod. 1984;16:149-52.

16. Akinboade OA, Dipeolu OO. Comparison of blood smear and indirect fluorescent antibody techniques in detection of haemoparasite infections in trade cattle in Nigeria. Vet Parasitol. 1984;14:95-104.

17. Ajayi SA, Fabi JP, Umo I. Clinical bovine anaplasmosis and babesiosis in Fresian cattle: an outbreak in Nigeria and its control. WId Anim Rev. 1982;6:41.

18. Obi TU. Survey of the incidence of anaplasmosis among Nigerian Zebu trade cattle. Trop Anim Health Prod. 1978:10:87-90.

19. Ajayi SA, Dipeolu OO. Prevalence of Anaplasma marginale, Babesia bigemina and B. bovis in Nigerian cattle using serological methods. Vet Parasitol. 1986; 22:147-9. 
20. Georges K, Loria GR, Riili S, Greco A, Caracappa S, Jongejan F, et al. Detection of haemoparasites in cattle by reverse line blot hybridisation with a note on the distribution of ticks in Sicily. Vet Parasitol. 2001;99: 273-86.

21. Schouls LM, Van De Pol I, Rijpkema SG, Schot CS. Detection and identification of Ehrlichia, Borrelia burgdorferi sensu lato, and Bartonella species in Dutch Ixodes ricinus ticks. J Clin Microbiol. 1999;37:2215-7.

22. Bekker CP, de Vos S, Taoufik A, Sparagano OA, Jongejan F. Simultaneous detection of Anaplasma and Ehrlichia species in ruminants and detection of Ehrlichia ruminantium in Amblyomma variegatum ticks by reverse line blot hybridization. Vet Microbiol. 2002;89:223-38.

23. Nijhof AM, Bodaan C, Postigo M, Nieuwenhuijs H, Opsteegh M, Franssen L, et al. Ticks and associated pathogens collected from domestic animals in the Netherlands. Vector Borne Zoonotic Dis. 2007;7:585-95.

24. Gubbels JM, de Vos AP, van der Weide M, Viseras J, Schouls LM, de Vries E, et al. Simultaneous detection of bovine Theileria and Babesia species by reverse line blot hybridization. J Clin Microbiol. 1999;37:1782-9.

25. Matjila PT, Leisewitz AL, Jongejan F, Penzhorn BL. Molecular detection of tick-borne protozoal and ehrlichial infections in domestic dogs in South Africa. Vet Parasitol. 2008;155:152-7.

26. Nijhof AM, Penzhorn BL, Lynen G, Mollel JO, Morkel P, Bekker CP, Jongejan F. Babesia bicornis sp. nov. and Theileria bicornis sp. nov.: tick-borne parasites associated with mortality in the black rhinoceros (Diceros bicornis). J Clin Microbiol. 2003;41:2249-54

27. Christova I, Van De Pol J, Yazar S, Velo E, Schouls L. Identification of Borrelia burgdorferi sensu lato, Anaplasma and Ehrlichia species, and spotted fever group Rickettsiae in ticks from Southeastern Europe. Eur J Clin Microbiol Infect Dis. 2002;22:535-42.

28. Majekodunmi AO, Fajinmi A, Dongkum C, Picozzi K, Thrusfield MV, Welburn SC. A longitudinal survey of African animal trypanosomiasis in domestic cattle on the Jos Plateau, Nigeria: prevalence, distribution and risk factors. Parasit Vectors. 2013;6:239.

29. Odumodu LO. Rainfall distribution, variability and probability in Plateau State. Nigeria J Clim. 1983:6:385-93.

30. Kikule SB. Age changes in the teeth of Zebu cattle. East Afr J Rural Dev. 1953;6:86-8

31. Ahmed HA, Picozzi K, Welburn SC, MacLeod ET. A comparative evaluation of PCR based methods for species specific determination of African animal trypanosomes in Ugandan cattle. Parasit Vectors. 2013;6:316.

32. Alberdi MP, Dalby MJ, Rodriguez-Andres J, Fazakerley JK, Kohl A, Bell-Sakyi L. Detection and identification of putative bacterial endosymbionts and endogenous viruses in tick cell lines. Ticks Tick Borne Dis. 2012;3:137-46.

33. Hall TA. BioEdit: a user-friendly biological sequence alignment editor and analysis program for Windows 95/98/NT. Nucleic Acids Symp Ser. 1999;41:95-8.

34. Vaumourin E, Vourc'h G, Telfer S, Lambin X, Salih D, Seitzer U, et al. To be or not to be associated: power study of four statistical modeling approaches to identify parasite associations in cross-sectional studies. Front Cell Infect Microbiol. 2014;154:62

35. Majekodunmi AO, Fajinmi A, Dongkum C, Shaw APM, Welburn SC. Pastora livelihoods of the Fulani on the Jos Plateau. Pastoralism Res Pol Prac. 2014;4 20.

36. Uilenberg $\mathrm{G}$, Robson J, Pedersen $\mathrm{V}$. Some experiments on the transmission of Theileria mutans (Theiler, 1906) and Theileria parva (Theiler, 1904) by the ticks Amblyomma variegatum (Fabricius, 1794) and Rhipicephalus appendiculatus (Neumann, 1901) in Uganda. Tropenmed Parasitol. 1974;25: 207-16

37. Young AS, Purnell RE, Payne RC, Brown CGD, Kanhai GK. Studies on the transmission and course of infection of a Kenyan strain of Theileria mutans. Parasitology. 1978;67:99-115.

38. Norval RAI, Perry BD, Young AS. 4. Tick vectors of theileriosis. In: The epidemiology of theieleriosis in Africa. Academic Press, London, U.K.; 1992. p. 100-4.

39. Aubry P, Geale DW. A review of bovine anaplasmosis. Transbound Emerg Dis. 2011;58:1-30.

40. Glover PE. The importance of ecological studies in the control of tsetse flies Bull World Health Organ. 1967;37:581-614.

41. Mahoney DF, Mirre GB. Bovine babesias: estimation of infection rates in the tick vector Boophilus microplus (Canestrini). Ann Trop Med Parasitol. 1971;65: 309-17.

42. Bock $R$, Jackson $L$, de Vos A, Jorgensen W. Babesiosis of cattle. Parasitology. 2004;129:S247-69.
43. Adetunji A, Akinboade OA, Dipeolu OO. Effect of experimental Babesia bigemina infection on the haematological values of splenectomized white Fulani calves. Rev Méd Vét Pays Trop. 1981;34:145-8.

44. Akinboade OA, Dipeolu OO. Detection of Babesia bovis infections in Boophilus geigyi with egg crushings, larval smears, and haemolymph puncture. Vet Q. 1981;6:143-7.

45. Andrew HR, Norval RAI. The carrier status of sheep, cattle, and African buffalo recovered from heartwater. Vet Parasitol. 1989;34:261-6.

46. Bishop R, Musoke A, Morzaria S, Gardner M, Nene V. Theileria: intracellular protozoan parasites of wild and domestic ruminants transmitted by ixodid ticks. Parasitology. 2004;129:S271-83.

47. Deem SL, Noval RA, Yonow T, Peter TF, Mahan SM, Burridge MJ. The epidemiology of heartwater: establishment and maintenance of endemic stability. Parasitol Today. 1996;12:402-5.

48. Adamu M, Troskie M, Oshadu DO, Malatji DP, Penzhorn BL1, Matjila PT. Occurrence of tick-transmitted pathogens in dogs in Jos, Plateau State, Nigeria. Parasit Vectors. 2014; 7:119.

49. Du Plessis JL. Increased pathogenicity of an Ehrlichia-like agent after passage through Amblyomma hebraeum: a preliminary report. Onderstepoort J Vet Res. 1990;57:233-7.

50. Woody BJ, Hoskins JD. Ehrlichial diseases of dogs. Vet Clin North Am Small Anim Pract. 1991;21:75-98.

51. Zobba R, Anfossi AG, Pinna Parpaglia ML, Dore GM, Chessa B, Spezzigu A, et al. Molecular investigation and phylogeny of Anaplasma spp. in Mediterranean ruminants reveal the presence of neutrophil-tropic strains closely related to A. platys. Appl Environ Microbiol. 2014;80:271-80.

52. Djiba ML, Mediannikov O, Mbengue M, Thiongane Y, Molez JF, Seck MT, et al. Survey of Anaplasmataceae bacteria in sheep from Senegal. Trop Anim Health Prod. 2013;45:1557-61.

53. Maggi RG, Mascarelli PE, Havenga LN, Naidoo V, Breitschwerdt EB. Coinfection with Anaplasma platys, Bartonella henselae and Candidatus Mycoplasma haematoparvum in a veterinarian Parasit Vectors. 2013;6:103.

54. Arraga-Alvarado CM, Qurollo B, Parra OC, Berrueta MA, Hegarty BC, Breitschwerdt EB. Case report: molecular evidence of Anaplasma platys infection in two women from Venezuela. Am J Trop Med Hyg. 2014;91: $1161-5$

55. Kamani J, Sannusi A, Egwu OK, Dogo Gl, Tanko TJ, Kemza S, et al. Molecular detection and characterization of tick-borne pathogens in dogs and ticks from Nigeria. PLoS Negl Trop Dis. 2013;7, e2108

56. Simpson RM, Gaunt SD, Hair JA, Kocan KM, Henk WG, Casey HW. Evaluation of Rhipicephalus sanguineus as a potential biologic vector of Ehrlichia platys. Am J Vet Res. 1991:52:1537-41.

57. Dantas-Torres F. Biology and ecology of the brown dog tick Rhipicephalus sanguineus. Parasit Vectors. 2010;3:26.

58. Beati L, Raoult L. Rickettsia massiliae sp. nov., a new spotted fever group Rickettsia. Int J Syst Bacteriol. 1993:43:839-40.

59. Parola P, Paddock CD, Socolovschi C, Labruna MB, Mediannikov O, Kernif T, et al. Update on tick-borne rickettsioses around the world: a geographic approach. Clin Microbiol Rev. 2013;26:657-702.

60. Cazorla C, Socolovschi C, Jensenius M, Parola P. Tick-borne diseases: tickborne spotted fever rickettsioses in Africa. Infect Dis Clin North Am. 2008;22: 531-44.

61. Coleman PG, Perry BD, Woolhouse ME. Endemic stability-a veterinary idea applied to human public health. Lancet. 2001;6:1284-6.

62. Njiiri NE, Bronsvoort BM, Collins NE, Steyn HC, Troskie M, Vorster I, et al. The epidemiology of tick-borne haemoparasites as determined by the reverse line blot hybridization assay in an intensively studied cohort of calves in western Kenya. Vet Parasitol. 2015;210:69-76.

63. Martins TM, Neves L, Pedro OC, Fafetine JM, Do Rosário VE, Domingos A. Molecular detection of Babesia spp. and other haemoparasitic infections of cattle in Maputo Province, Mozambique. Parasitology. 2010;137:939-46. 